\title{
Autophagy as a consequence of seasonal functions of testis and epididymis in adult male European bison (Bison bonasus, Linnaeus 1758)
}

\author{
Anna Tabecka-Lonczynska ${ }^{1}$ (D) Jennifer Mytych ${ }^{1} \cdot$ Przemyslaw Solek $^{1} \cdot$ Marek Koziorowski $^{1}$
}

Received: 2 December 2018 / Accepted: 22 September 2019 / Published online: 8 November 2019

(C) The Author(s) 2019

\begin{abstract}
The European bison is still an animal endangered with extinction, so by learning factors that regulate its reproduction, we can contribute to the survival of this species. On the other hand, autophagy is a dynamic, lisosomal, and evolutionary conserved process which is essential for animal cell survival, homeostasis, and differentiation. This process was demonstrated in many species and in many organs; however, information on the metabolic course of autophagy in the male reproductive system in seasonally reproducing species is lacking. Therefore, in this study, we examined for the first time several autophagy-related factors (mTOR, ULK1, Atg13, PI3K, beclin1, beclin2, Atg14, Atg5, Atg16L, LC3) in testicular and epididymal tissues obtained from adult male individuals of the European bison. We compared the level of gene expression, protein synthesis, and localization of autophagy-related factors between June, September, and December (before, during, and after reproductive activity, respectively). We confirmed that the induction of autophagy was at the highest level in the period after reproductive activity, i.e., in December, when a significant increase in the gene and protein expression was observed for the majority of these factors, probably to ensure cellular protection. However, autophagy was also clearly marked in September, during the intense spermatogenesis, and this may indicate a great demand for autophagy-related proteins required for the normal development of reproductive cells. Obtained results seem to confirm that autophagy pathway, as a consequence of seasonal reproduction, may control the normal course of spermatogenesis in the male European bison.
\end{abstract}

Keywords Autophagy $\cdot$ Testis $\cdot$ Epididymis $\cdot$ Seasonal reproduction $\cdot$ European bison

\section{Introduction}

The endangered European bison (Bison bonasus) is a seasonally breeding animal with a clearly marked increase in the reproductive activity at the turn of August and September. In the European bison, the seasonality of reproduction results from cyclical changes in the structure and activity of the testis and the epididymis, and indicates the presence of molecular mechanisms responsible for the stimulation of cell proliferation and the induction of spermatogenesis in the reproductive period. These processes are strictly regulated not only by a

Anna Tabecka-Lonczynska

annaurz@wp.pl

1 Department of Animal Physiology and Reproduction, Institute of Biology and Biotechnology, Collegium Scientarium Naturalium, University of Rzeszow, Werynia 502, 36-100 Kolbuszowa, Poland normal function of the hypothalamic-pituitary-gonadal axis, but it also was demonstrated that local mechanisms have a great impact on them (McGuire et al. 2011; TabeckaLonczynska et al. 2018b; Tabecka-Lonczynska et al. 2017). The normally functioning male reproductive system produces wholesome reproductive cells spermatozoa, with Leydig and Sertoli cells involved in this process. Leydig cells stimulate the process of spermatogenesis and are responsible for the production of androgens, mainly testosterone, while Sertoli cells are responsible for providing nutrients, and for regulating proliferation and maturation of reproductive cells (Kim et al. 2010; Zirkin and Papadopoulos 2018). When their functions are fulfilled, these cells are probably silenced, although the relevant molecular process has not yet been discovered. Interestingly, recent reports indicate the involvement of autophagy in seasonal reproduction (Gonzalez et al. 2018).

Autophagy is an evolutionary conserved physiological process regulating cellular degradation by phagocytosis of 
cellular organelles and proteins (Levine and Klionsky 2004). This multi-stage process takes place through sequestration of cytosolic material surrounded by double-lipid membranes, which is then degraded and digested (Bartsch et al. 2016). It enables cell survival through recycling of nucleotides, as well as of amino acids and free fatty acids. They are re-used both for molecular synthesis and as ATP for energy generation (Zhang et al. 2012). Molecular mechanisms of autophagy are strictly dependent on the autophagy-related genes (ATG genes), which were found to be conserved in mammals (Wen and Klionsky 2016; Yang and Klionsky 2010). Autophagy is type II, while apoptosis is type I-programmed cell death. To date, some dependencies between autophagy and apoptosis were identified (Eisenberg-Lerner et al. 2009); however, this area needs to be further investigated. It was demonstrated that autophagy is responsible for cell differentiation, malignant proliferation, development, and homeostasis (Li et al. 2011; Mizushima and Levine 2010). Furthermore, it was shown that autophagy is a key process regulating testicular development (Huang and Li 2014) and spermatogenesis (Wang et al. 2014); however, exact mechanisms have not been proposed.

There are still many unknowns in this equation aiming to explain the seasonal reproductive activity of male European bison. The autophagy process seems to be of great importance, as a mechanism protecting the course of proper spermatogenesis. Thus, the aim of this study was to determine the exact course of subsequent stages of the autophagy pathway in the reproductive system of the male European bison before, during, and after breeding season. The understanding of the impact of autophagy on the regulation of reproductive processes may contribute to the European bison protection as a species threatened with extinction.

\section{Materials and Methods}

\section{Animals and tissue collecting}

Testicular and epididymal tissue fragments were collected from European bison (Bison bonasus, Linnaeus 1758) bulls aged 4 to 12 years $(n=6)$ and weighing from 500 to $650 \mathrm{~kg}$. The samples from different animals were analyzed separately. Animals lived in Bialowieza National Park and Bialowieza Forest and were shot in the spine as a result of selective eliminations in the seasons of $2010 / 2011,2011 / 2012$, and 2012/2013, in June, September, and December (before, during, and after the breeding period, respectively). The total time of formation of tribes takes about 2 months; therefore, it can be assumed that in June, the preparatory period for the spermatogenesis process begins. All procedures were conducted in accordance with the relevant animal welfare legislation provided for in the Polish law. For preservation of RNA and proteins, all tissues were snap frozen in liquid nitrogen $(-196$ ${ }^{\circ} \mathrm{C}$ ) and afterwards kept at $-80^{\circ} \mathrm{C}$ until further analyses.

\section{RNA isolation, reverse transcription, and RT PCR analysis}

The total RNA was extracted using the column-based kit (A\&A Biotechnology, Gdynia, Poland) following the manufacturer's protocol. Biological repeats $(n=6)$ were carried out in triplicates. The DNAse treatment included in the kit was performed according to the instructions. The concentration of extracted total RNA was quantified using the NanoDrop 2000 Spectrophotometer (Thermo Fisher Scientific Inc., Waltham, MA, USA), and the RNA integrity was evaluated through the $1.0 \%$ agarose gel electrophoresis. Subsequently, cDNA was prepared from $1 \mu \mathrm{g}$ of total RNA using High Capacity cDNA Reverse Transcription Kit as previously described (Tabecka-Lonczynska et al. 2017). Afterwards, 1 ug RNA was diluted with sterile water and then mixed with $10 \mu \mathrm{l}$ of master mix prepared freshly before use $(2 \mu \mathrm{l}$ of $10 \times \mathrm{RT}$ Buffer, $0.8 \mu \mathrm{l}$ of $25 \times$ dNTP Mix, $2 \mu \mathrm{l}$ of $10 \times$ RT Random Primers, $1 \mu \mathrm{l}$ of Multiscribe Reverse Transcriptase, and $3.2 \mu \mathrm{l}$ $\mathrm{H}_{2} \mathrm{O}$ ). RT reactions were conducted in a Thermocycler (Biometra, Gőttingen, Germany) according to recommended conditions $\left(25^{\circ} \mathrm{C}-10 \mathrm{~min}, 37^{\circ} \mathrm{C}-120 \mathrm{~min}, 85^{\circ} \mathrm{C}-5 \mathrm{~min}\right)$.

Primers specific to ACTB ( $\beta$-actin) and autophagy metabolic pathway genes: ULK1, mTOR, PI3K, beclin1 (BECN1), beclin2 (BECN2), Atg16L, and $L C 3$, were commercially synthesized (Genomed, Warsaw, Poland). Primers for the genes: mTOR (Marcais et al. 2014), ULK1 (Thomas et al. 2008), PI3K (Kim et al. 2017), BECN1 (Zielniok et al. 2017), $B E C N 2$ (Singh et al. 2014), Atg16L (Ouimet et al. 2016), LC3 (Aboelenain et al. 2015), and ACTB (TabeckaLonczynska et al. 2018a) were synthesized on a basis of the reported sequences found in the literature. All primer sequences are presented in Table 1.

Five microliters of the PCR master mix $2 \times$ PCRTaqNovaRED (DNA Gdansk; Gdansk, Poland), $4 \mu$ l of primers ( $2 \mu \mathrm{l}$ of each of the $1 \mu \mathrm{M}$ forward and reverse primers) (Genomed; Warsaw, Poland), and $1 \mu \mathrm{l}$ of cDNA (50 ng) in a volume of $10 \mu \mathrm{l}$ were used in the PCR reactions. The PCR amplification was conducted for 35 cycles: denaturing at $95{ }^{\circ} \mathrm{C}$ for $45 \mathrm{~s}$, annealing at $53{ }^{\circ} \mathrm{C}(U L K 1), 53{ }^{\circ} \mathrm{C}(m T O R), 53.5^{\circ} \mathrm{C}(P I 3 K)$, $52{ }^{\circ} \mathrm{C}\left(\right.$ BECN1), $56{ }^{\circ} \mathrm{C}\left(\right.$ BECN2), $53{ }^{\circ} \mathrm{C}$ (ATG16), $52{ }^{\circ} \mathrm{C}$ (LC3), or $55^{\circ} \mathrm{C}(A C T B)$ for $45 \mathrm{~s}$, and extension at $72{ }^{\circ} \mathrm{C}$ for $45 \mathrm{~s}$, followed by the final extension at $72{ }^{\circ} \mathrm{C}$ for $10 \mathrm{~min}$. Then, the obtained PCR products were detected by gel electrophoresis in the $1 \%$ agarose gel stained with ethidium bromide. The GelQuantNET software was used to calculate the optical density of bands, and values were numerically expressed as the relative density. The expression levels of the target genes were determined in comparison to the 
Table 1 Oligonucleotide primers used for RT-PCR in this study

\begin{tabular}{|c|c|c|c|}
\hline $\begin{array}{l}\text { Target } \\
\text { gene }\end{array}$ & $\begin{array}{l}\text { Forward primer sequence } \\
\left(5^{\prime}-3^{\prime}\right)\end{array}$ & $\begin{array}{l}\text { Reverse primer sequence } \\
\left(5^{\prime}-3^{\prime}\right)\end{array}$ & Ref. \\
\hline$m T O R$ & $\begin{array}{l}\text { ACCGGCACACATTT } \\
\text { GAAGAAG }\end{array}$ & $\begin{array}{l}\text { CACCACCAAGGATA } \\
\text { AGGTAG }\end{array}$ & Marcais et al. 2014 \\
\hline$U L K 1$ & $\begin{array}{l}\text { AGGATGGGGACTTG } \\
\text { GTTGC }\end{array}$ & $\begin{array}{l}\text { CGATGTTTTCGTGC } \\
\text { TTTAGTTCC }\end{array}$ & Thomas et al. 2008 \\
\hline PI3K & $\begin{array}{l}\text { CCTGGACATCAACG } \\
\text { TGCAG }\end{array}$ & $\begin{array}{l}\text { TGTCTCTTGGTATA } \\
\text { GCCCAGAAA }\end{array}$ & Kim et al. 2017 \\
\hline$B E C N 1$ & $\begin{array}{l}\text { AGTTGAGAAAGGCG } \\
\text { AGACAC }\end{array}$ & $\begin{array}{l}\text { CACCACCAAGGATA } \\
\text { AGGTAG }\end{array}$ & Zielniok et al. 2017 \\
\hline$B E C N 2$ & $\begin{array}{l}\text { GTCGCTACCGTCGT } \\
\text { GACTTC }\end{array}$ & $\begin{array}{l}\text { CAGACATGCACCTA } \\
\text { CCCAGC }\end{array}$ & Singh et al. 2014 \\
\hline ATG16L & $\begin{array}{l}\text { CAGAGCAGCTACTA } \\
\text { AGCGACT }\end{array}$ & $\begin{array}{l}\text { AAAAGGGGAGATTC } \\
\text { GGACAGA }\end{array}$ & Ouimet et al. 2016 \\
\hline$L C 3$ & $\begin{array}{l}\text { CGAGAGCAGCATCC } \\
\text { TACCAA }\end{array}$ & $\begin{array}{l}\text { TTCTTCCGCGAATG } \\
\text { TCGAGT }\end{array}$ & Aboelenain et al. 2015 \\
\hline$A C T B$ & $\begin{array}{l}\text { CATCGGCAATGAGC } \\
\text { GGTTCC }\end{array}$ & $\begin{array}{l}\text { CCGTGTTGGCGTAG } \\
\text { AGGTCC }\end{array}$ & $\begin{array}{l}\text { Tabecka-Lonczynska et al. } \\
2017\end{array}$ \\
\hline
\end{tabular}

expression level of $A C T B$, which was chosen as a reference gene on a basis of available literature (Schmidt et al. 2007).

\section{Protein isolation and Western blot analysis}

To determine the protein expression, equal amounts of frozen testicular and epididymal tissues ( $n=6$, in triplicates) were homogenized in 2\% SDS (Sigma, Saint Louis, MO, USA) with the lysing matrix D (MP Biomedicals), using a highspeed benchtop homogenizer system FastPrep 24 MP (3 times for $20 \mathrm{~s}$ in every cycle). The homogenates were clarified by centrifugation at $15,000 \mathrm{~g}$ at $4{ }^{\circ} \mathrm{C}$ for 15 min to obtain supernatants. Total protein contents were determined according to the BCA protein assay procedure (Thermo Scientific, Warsaw, Poland), using bovine serum albumin (BSA) (BioShop, Burlington, Canada) as a calibration standard. Furthermore, $30 \mu \mathrm{g}$ of proteins were separated by $10 \%$ SDS-PAGE under reducing conditions, and the proteins were transferred onto a polyvinylidene difluoride membrane (Merck Millipore). Next, the membranes were washed, and nonspecific binding sites were blocked with $1 \%$ BSA in TBST buffer (20 mMTris$\mathrm{HCl} \mathrm{pH} \mathrm{7.5,} 137 \mathrm{mMNaCl}, 0.1 \%$ Tween 20) at the room temperature $\left(21^{\circ} \mathrm{C}\right)$ for $1 \mathrm{~h}$, and then incubated overnight with the following primary antibodies: rabbit polyclonal against mTOR (1:1000; \#PA534663, RRID: AB_2552015; Thermo Scientific), rabbit polyclonal against ULK1 (1:1000; \#PA526126, RRID: AB_2543626; Thermo Scientific), rabbit polyclonal against Atg13 (1:1000; \#PA526923, RRID: AB 2544423; Thermo Scientific), rabbit polyclonal against beclin1 (1:1000; \#PA116857, RRID: AB 568459; Thermo Scientific), mouse monoclonal against beclin2 (1:500; \#sc7382, RRID: AB 626736; Santa Cruz), rabbit polyclonal against Atg14 (1:1000; \#PA534972, RRID: AB_2552321; Thermo Scientific), rabbit polyclonal against Atg5 (1:1000; \# PA5-23186, RRID: AB_2540712; Thermo Scientific), polyclonal rabbit against Atg16L1 (1:1000; \#PA1-46307, RRID: AB_2059398; Thermo Scientific), polyclonal rabbit against LC3A/B (1:1000, \#PA1- 16931, RRID: AB_2137583; Thermo Scientific), or rabbit polyclonal against ACTB (1:10,000; \#PA1-16889, RRID: AB_568434; Thermo Scientific), prepared in 1\% BSA in TBST. Following incubation with the primary antibody, the membranes were washed with TBST four times for 5 min and incubated for $1 \mathrm{~h}$ with horseradish peroxidase-conjugated secondary antibodies: anti-rabbit IgG (1:80,000; \#A0545, RRID: AB_257896; Sigma), or anti-mouse IgG (1:80,000; \#A9044, RRID: AB_258431; Sigma). The blots were visualized using the ECL Western Blotting kit (BioRad) and the Fusion Fx7 (Viber Lourant) system. The densitometric analysis was performed using the GelQuantNET software. The bands were quantified and normalized to their corresponding $\beta$-actin bands.

\section{Immunohistochemistry}

Immunohistochemistry of Atg13, Atg14, beclin1, and Atg5 proteins in the testis tissue was performed using a method described in the previous report, with some modifications (Tabecka-Lonczynska et al. 2017). Tissue sections $(4 \mu \mathrm{m})$ embedded in Paraplast Plus (Sigma Aldrich; Darmstadt, Germany) were placed on Super Frost ${ }^{\circledR}$ microscope slides (Menzel-Glaeser, Braunschweig, Germany); then retrieved by boiling in $0.01 \mathrm{M}$ citrate buffer of $\mathrm{pH} 6.0$ in a microwave oven at $700 \mathrm{~W}, 3$ times for $5 \mathrm{~min}$. After cooling to the room temperature, the sections were blocked in $1 \%$ BSA in PBST for $30 \mathrm{~min}$. Next, the slides were incubated with the primary polyclonal rabbit anti-Atg13 (\#PA526126, RRID: AB 2543626; Thermo Scientific), anti-Atg14 (\#PA534972, RRID: AB_2552321; Thermo Scientific), anti-beclin1 (\#PA116857, RRID: AB_568459; Thermo Scientific), and 
anti-Atg5 (\# PA5-23186, RRID: AB 2540712; Thermo Scientific) antibodies (dilution 1:100, 1:500, 1:500, and 1:500; respectively) at $4{ }^{\circ} \mathrm{C}$, overnight. On the following day, the slides were rinsed and incubated with the anti-rabbit secondary antibody conjugated with HRP (horseradish peroxidase). After $1 \mathrm{~h}$ incubation in RT, the presence of the analyzed proteins was detected by DAKO Real EnVisoin-HRP System (Glostrup; Denmark). In a negative control, the primary antibody was replaced with PBST. The slides were dehydrated in a graded ethanol series, equilibrated in xylene, and mounted in DPX (Merck KGaA, Darmstadt, Germany). Digital images of minimum six testis sections were analyzed using the Olympus BX 43 microscope equipped with the soft cell Sens Dimention software and the public domain Image J software.

\section{Statistical analysis}

Statistical analyses were performed using GraphPadPism 6.0. All data is presented as the grand mean \pm SD and analyzed with a one-way ANOVA followed by Dunnett's multiple comparison post hoc test in all quantifying analyses (RT PCR, Western blot, and immunohistochemistry). The differences were considered statistically significant at the $95 \%$ confidence level $(p<0.05)$ and are presented as: $*, p<0.05 ; * *, p<0.01$; $* * *$, and $p<0.001$.

\section{Results}

Western blot, RT PCR, and immunohistochemistry analyses were conducted to evaluate the differences in the expression levels of proteins and genes related to autophagy in the testis and the epididymis of the adult European bison between June, September, and December.

The first factor deciding about the induction of autophagy is mTOR kinase, which acts as a sensor for cellular levels of energy compounds, growth factors, and nutrients. The analysis of mTOR protein synthesis $(288 \mathrm{kDa})$ for both testis and epididymis revealed that it reached its highest level in September. This level in the testis was 11.366-fold higher than in June and 2.393-fold higher than in December $(p<0.01, p<$ 0.01 , respectively). In epididymis, its values were 13.583 -fold higher than in June and 5.636-fold than in December (Fig. 1a; Fig. 2). On the other hand, in the testis, mRNA gene expression for $m T O R$ was more pronounced in June (3.018-fold) and December (2.553-fold) than in September $(p<0.001, p<$ 0.001; respectively) (Fig. 3a, h). At the same time, no differences in the $m T O R$ gene expression were observed in the epididymis $(p<0.05)$ (Fig. 3a, h).

At the nucleation stage, ULK1 together with Atg13 initiate creation of autophagosomes, by modulating formation of insulating membranes. In testicular and epididymal tissues, the highest expression of ULK1 protein $(116 \mathrm{kDa})$ synthesis was
Fig. 1 a mTOR, b ULK1, c Atg13, d beclin1, e Atg14, f beclin2, $\mathbf{g}$ Atg5, h Atg16L, i LC3, j NUP62 protein levels analyzed by Western blot technique in June (VI), September (IX), and December (XII) in European bison testis and epididymis. Bars indicate mean $\pm \mathrm{SD}, n=$ min 6 per each period and tissue, $* * * p<0.001,{ }^{*} p<0.01, * p<0.05$; no indication - no statistical significance $(p>0.05)$ (one-way ANOVA with Dunnett's a posteriori test)

detected in December, when compared to June $(p<0.001)$, and was 10.044-fold higher. In the testis, the difference between June and September was also detectable, with 6.391fold higher level in September $(p<0.05)$. At the same time, no significant difference between June and September was noted in the epididymis $(p>0.05)$, but its 4.764 -fold higher level was found in December versus June $(p<0.001)$ (Fig. 1b; Fig. 2). The quantitative RT PCR analysis revealed that the level of ULK1 mRNA expression in the testis was 1.458-fold higher in September than in December $(p<0.05)$. In the epididymis, its expression level was higher in September, when compared to both June (5.076-fold) and December (8.361-fold) $(p<0.001$; $p<0.001$, respectively) (Fig. 3b, h).

The measurements of the Atg13 (65 kDa) protein level in the testis revealed that it reached its highest value in September, and was 3.427-fold higher than in June $(p<$ $0.001)$ and 4.579-fold higher than in December $(p<0.001)$ (Fig. 1c; Fig. 2). Atg13 protein, an essential protein for autophagy induction by the ULK1 complex, was found in all analysed months and cells (Fig. 4a, b, c, g). Immunohistochemical results confirmed results obtained for the western blot, and in Sertoli cells demonstrated the highest level of the relative optical density in September, when compared to June $(p<0.001)$ and December $(p<0.001)$. In Leydig cells, the Atg13 level was significantly higher both in September $(p<0.001)$ and in December $(p<0.001)$, in relation to June (Fig. 4a, b, c, g).

In the next stage, PI3K mediates the nucleation of vesicles. In the testis, the mRNA gene expression of $P I 3 K$ did not show any changes during the analyzed periods $(p>0.05)$; however, in the epididymal tissues, the observed level was higher in September, when compared to June (4.664-fold) $(p<0.001)$ and December (5.689-fold) ( $p<0.001)$ (Fig. 3c, h).

Beclin1 $(60 \mathrm{kDa})$ takes part in vesicle nucleation and was detected in the testis, with the highest level of that protein expression in December, when it was 2.972-fold higher than in June $(p<0.001)$ and 3.926-fold higher than in September $(p$ $<0.001$ ) (Fig. 1d; Fig. 2). In the epididymis, the level of beclin1 protein expression did not differ between analyzed months ( $p>0.05$ ) (Fig. 1d; Fig. 2), while the measured $B E C N 1$ gene expression in the testis was strongly increased in September, and its level was significantly higher than in June $(1.489$-fold $)(p<0.05)$ and December $(1.462$-fold $)(p<$ 0.05 ) (Fig. $3 \mathrm{~d}, \mathrm{~h}$ ). In testis cells, beclin1 was detectable in all analyzed periods with the highest values of the relative optical 

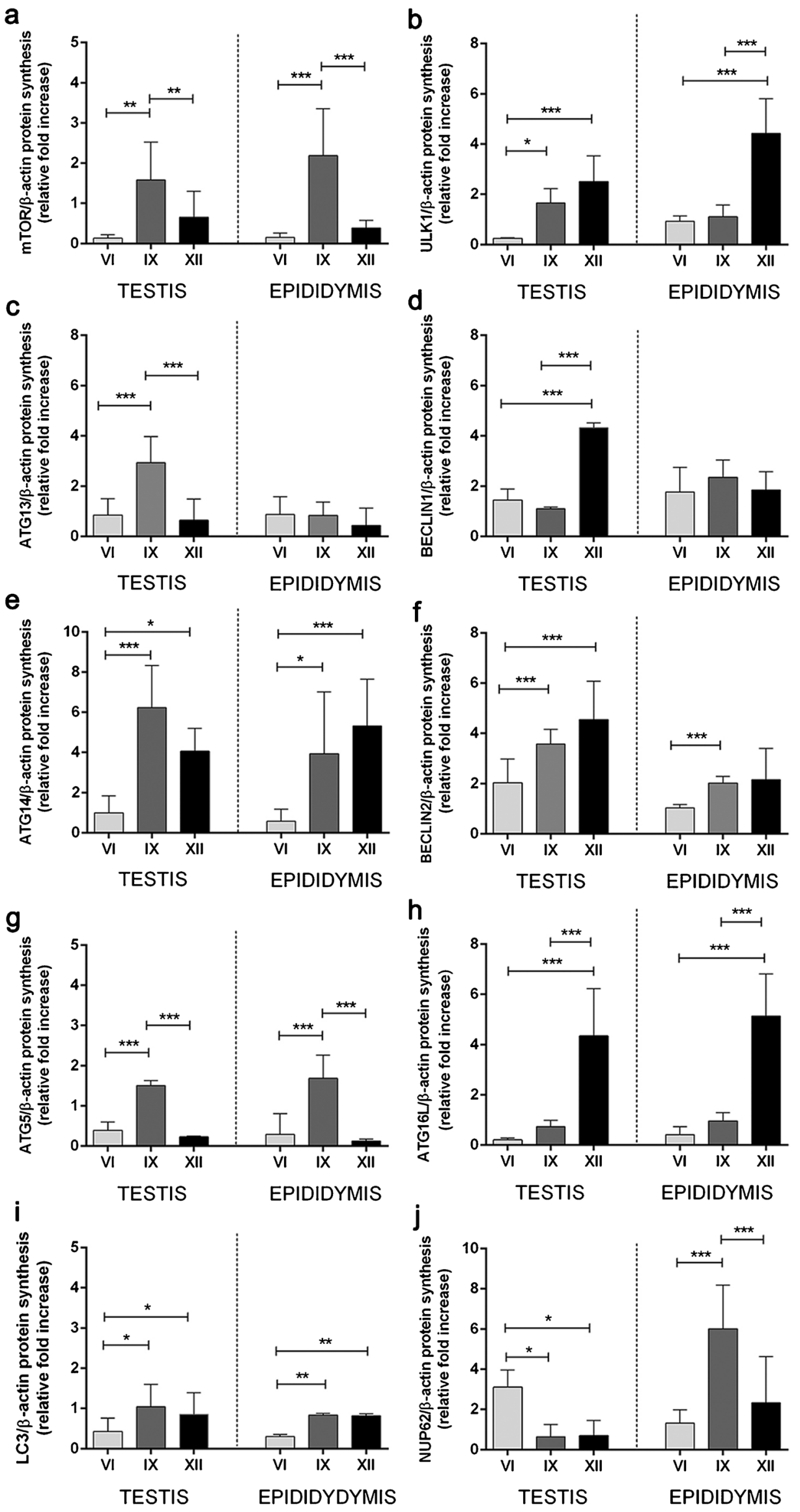


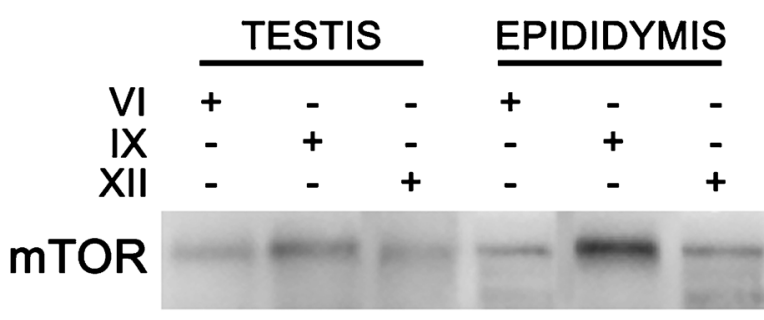

\section{ULK1}

\section{ATG13}

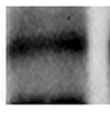

BECLIN1

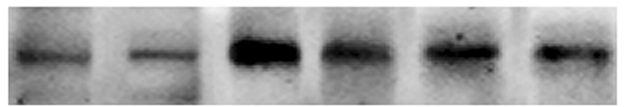

ATG14

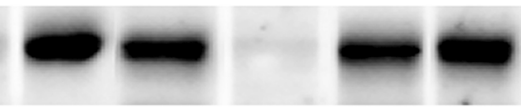

BECLIN2

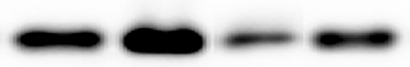

ATG5

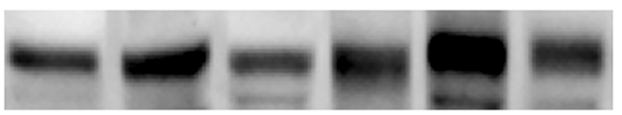

ATG16L
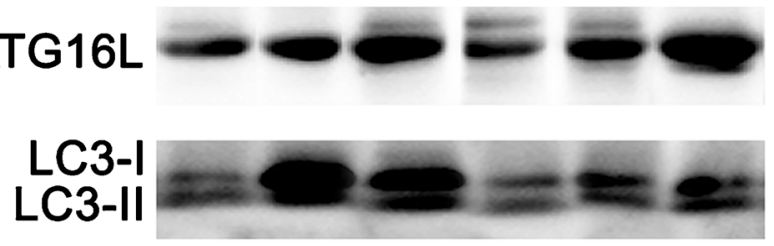

\section{NUP62}
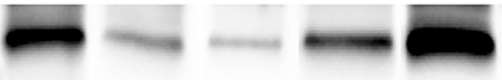

\section{B-ACTIN}

Fig. 2 Representative Western blots of mTOR, ULK1, Atg13, beclin1, Atg14, beclin2, Atg5, Atg16L, LC3, NUP62, and $\beta$-actin proteins in European bison testis and epididymis in June (VI), September (IX), and December (XII)

density in September, versus June $(p<0.001)$ and December $(p<0.001)$ (Fig. 4d, e, f, h).

The level of Atg14 (60 kDa) protein, as a regulator of the autophagosome formation in the testis was characterized by the significantly elevated expression in September (6.214fold) $(p<0.001)$ and December $(1.553$-fold $)(p<0.05)$, in comparison to June (Fig. 1e; Fig. 2). Similar results were observed in the epididymis, where the Atg14 protein expression was 1.35-fold higher in September $(p<0.05)$ and 6.7 -fold higher in December $(p<0.001)$ than in June (Fig. 1e, Fig. 2).
Positive Atg14 staining was also localized in the testis in Sertoli and germ cells with its level higher in June and December, when compared to September (for Sertoli cells: $p$ $<0.001$ and $p<0.001$, respectively, and for germ cells: $p<$ 0.05 and $p<0.01$, respectively). In Leydig cells, no differences were found in the localization of Atg14 between the periods $(p>0.05)$ (Fig. 5a, b, c, g).

The beclin2 protein inhibits the activity of the beclin1 and PI3K complex. Its expression $(26 \mathrm{kDa})$ in the testis was markedly elevated in December $(2.224$-fold $)(p<0.001)$, but also in September $(p<0.001)$, in relation to June (Fig. 1f; Fig. 2). In the epididymis, the statistically significant higher level of beclin2 expression was observed only in September, when compared to June, and it was 1.95 -fold higher $(p<0.001)$ (Fig. 1f; Fig. 2). When analyzing the mRNA gene expression for $B E C N 2$ in testis, its level was higher in June, in comparison to September $(2.053$-fold $)(p<0.01)$ and December (1.534-fold) $(p<0.05)$ (Fig. 3e, h).

Another protein that mediates the growth of autophagosomal vesicles is Atg5 (56 kDa), and in the testis, its expression level reached the highest values in September, with the observed level being 3.836-fold higher than in June $(p<0.001)$ and 6.51-fold higher than in December $(p<0.001)$ (Fig. 1g; Fig. 2). Also in the epididymis, the Atg5 level was the highest in September (5.78-fold higher than in June and 13.504-fold higher than in December) $(p<0.001$, and $p<$ 0.001 , respectively) (Fig. 1g; Fig. 2). The significant presence of the Atg5 protein in germ and Leydig cells in September confirms the results obtained for the western blot while in Sertoli cells, the highest values of relative optical density were recorded in December, versus June $(p<0.05)$ (Fig. 5d, e, f, h).

At the same time, the expression level of the Atg16L protein $(68 \mathrm{kDa})$, which is responsible for the extension of the membrane that isolates autophagosomic vesicles, was also the highest in December, both in the testis and the epididymis. The observed difference was 20.728-fold higher than in June $(p<0.001)$ and 5.954-fold higher than in September $(p<$ $0.001)$ for testis and 12.277-fold higher than in June ( $p<$ $0.001)$ and 5.318-fold higher than in September $(p<0.001)$ for epididymis (Fig. 1h; Fig. 2). RT PCR results for $A T G 16 L$ confirm results obtained for the western blot, and in the testis they were 1.788-fold more pronounced in September than in June $(p<0.01)$, while in the epididymis, in September, they were 2.548-fold higher versus June and 3.933-fold higher versus December ( $p<0.001, p<0.001$; respectively) (Fig. 3f, h).

The LC3 protein is involved in the final stage of the autophagy process, and it participates in expanding of the autophagosome membrane. It has two forms: the cytoplasmic form (LC3-I; $19 \mathrm{kDa}$ ), that can be converted to the membrane form (LC3-II; $17 \mathrm{kDa}$ ), enabling evaluation of the autophagy level by the western blot (Fig. 1i, Fig. 2). The LC3-II/LC3-I protein expression was significantly increased in the testis; and it was 2.439-fold higher in September and 1.222-fold 
a

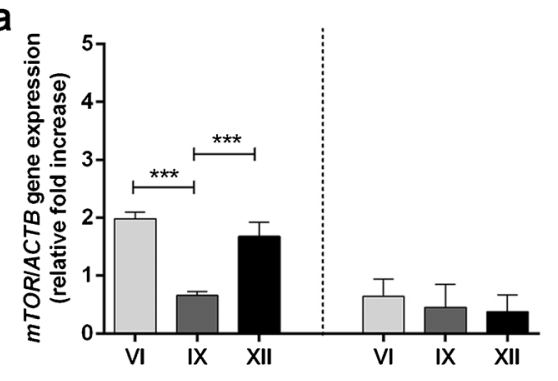

C

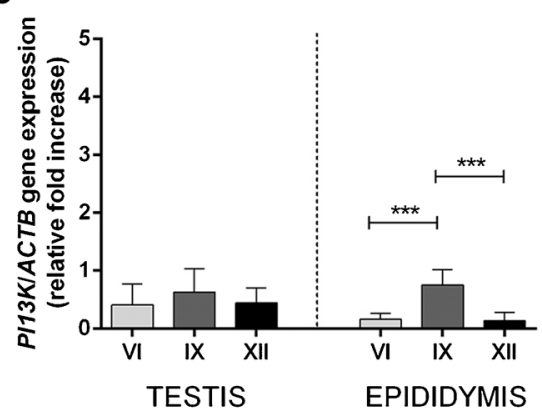

e

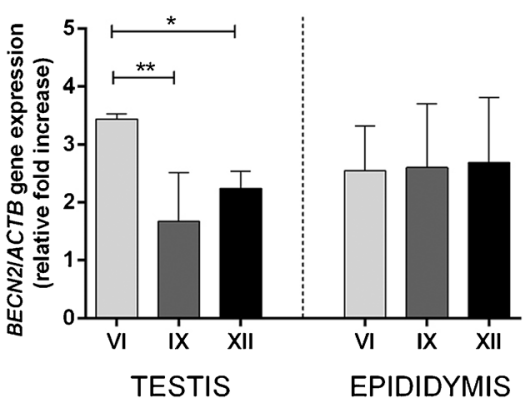

b
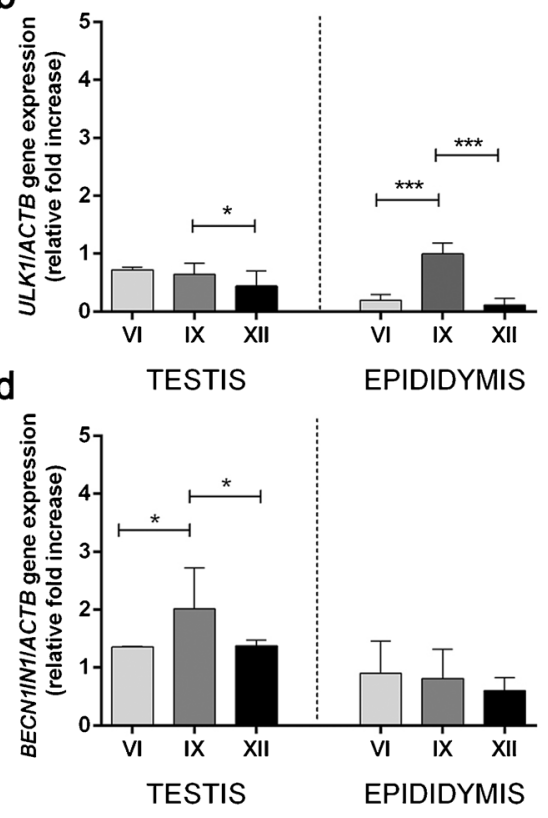

$f$

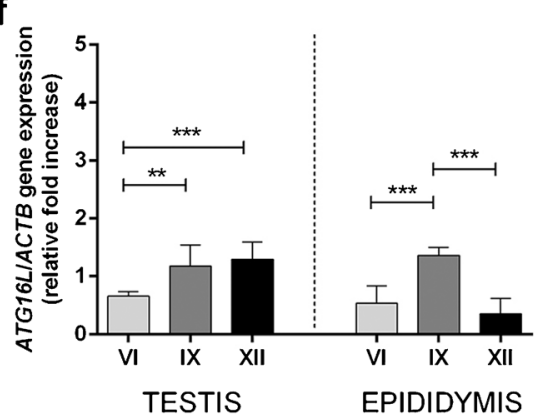

h
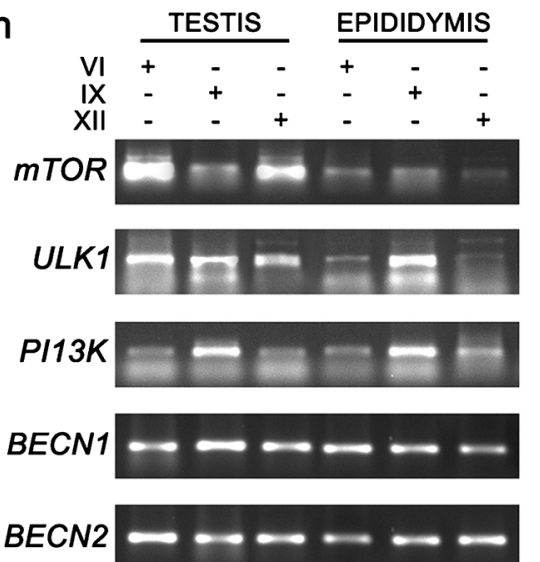

ATG16L $= \pm= \pm-$

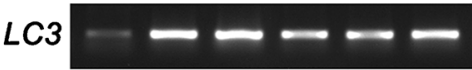

ACTB -----

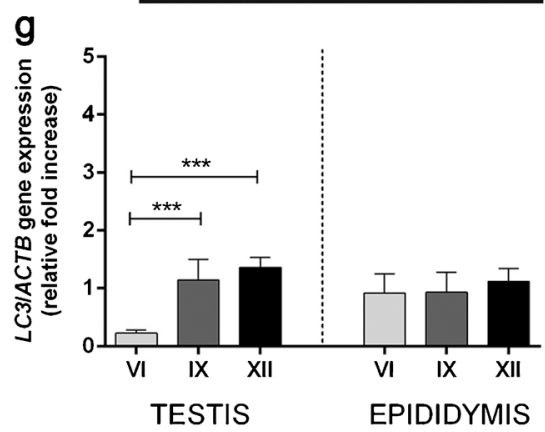

Fig. 3 mRNA expression of a $m T O R$, b $U L K 1$, c $P I 3 K$, d $B E C N 1$, e $B E C N 2$, $\mathbf{f} \operatorname{Atg} 16 L$, and $\mathbf{g} L C 3$ analyzed by RT PCR technique in June (VI), September (IX), and December (XII) in European bison testis and epididymis. h Representative images of gel. Bars indicate mean $\pm \mathrm{SD}, n=$

higher in December, in comparison to June $(p<0.05 ; p<0.05$, respectively). In the epididymis, the LC3-II/LC3-I protein expression ratio was characterized by the highest difference between June and September (2.805-fold higher in September) $(p<0.01)$, but a significant difference was also observed between June and December (2.748-fold higher in December) ( $p$ $<0.01$ ) (Fig. 1i; Fig. 2). Moreover, in the testis, the results for the $L C 3$ gene expression confirmed the results for the protein expression, where values obtained for September and December were significantly higher, when compared to June (4.935-fold, and 5.862-fold, respectively) ( $p<0.001, p<$ 0.001 , respectively). In the epididymis, no difference in $L C 3$ gene expression levels was observed between the analyzed months $(p<0.05)$ (Fig. 3 g, h).

Nup62 protein $(62 \mathrm{kDa})$ is a scaffolding protein enabling a transfer of ubiquitinated proteins into autophagosomes. In the testis, the Nup62 protein expression was significantly higher in June when compared to September $(4.894$-fold $)(p<0.05)$ and December $(4.485$-fold) $(p<0.05)$. In the epididymis, its min 6 per each period and tissue, $* * * p<0.001, * * p<0.01, * p<0.05$; no indication - no statistical significance $(p>0.05)$ (one-way ANOVA with Dunnett's a posteriori test). The results were normalized to ACTB

level in September was 4.567-fold higher versus June $(p<$ $0.001)$ and 2.579-fold higher versus December $(p<0.001)$ (Fig. 1j; Fig. 2).

\section{Discussion}

In this study, we evaluated for the first time the role of the autophagy pathway in the control of seasonal reproduction in the male European bison, an animal with a strongly marked breeding seasonality, at the turn of August and the beginning of September (Tabecka-Lonczynska et al. 2017). We confirmed the induction of the autophagy process in both, the testis and the epididymis. By analyzing the metabolic pathway within the autophagy process, we observed the highest induction of autophagy in December, when the animal body was preparing for the "reproductive silence." Nevertheless, this process was also active to some degree in September, when intense spermatogenesis takes place. 

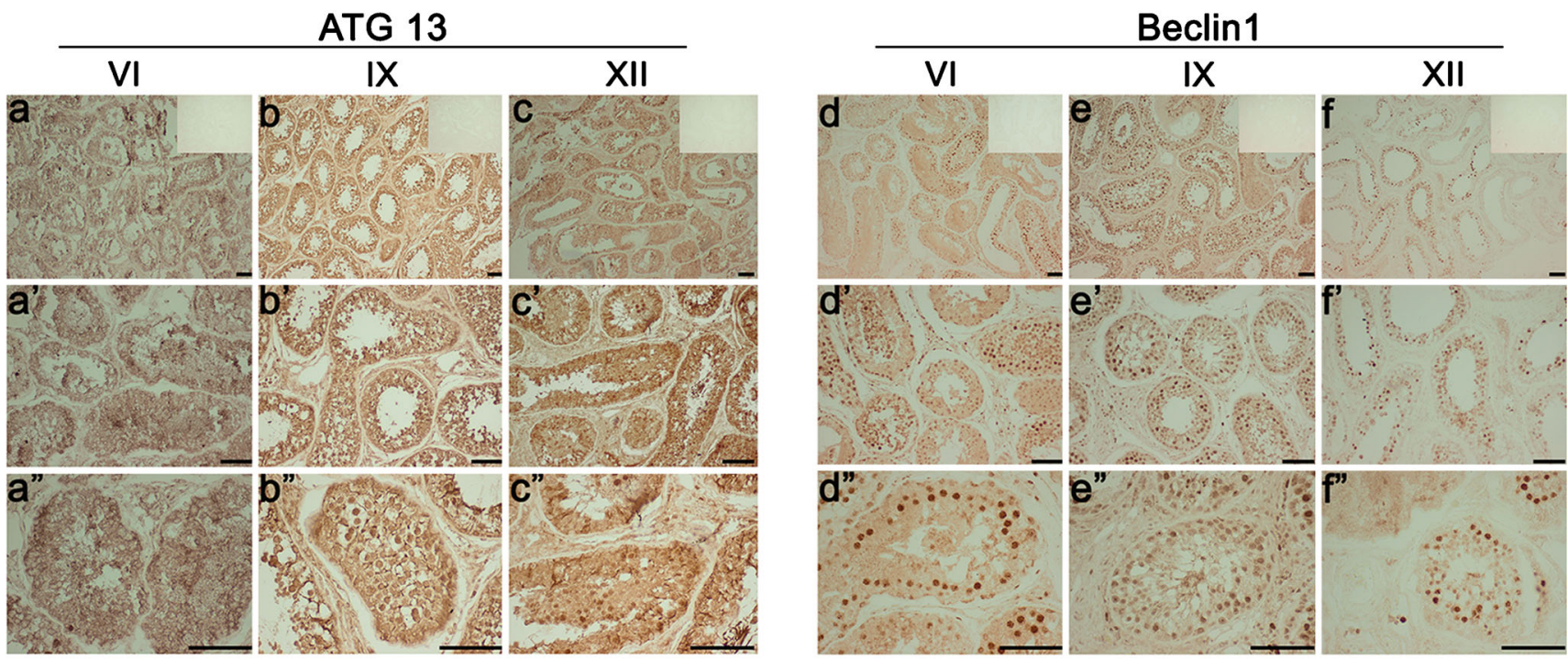

g

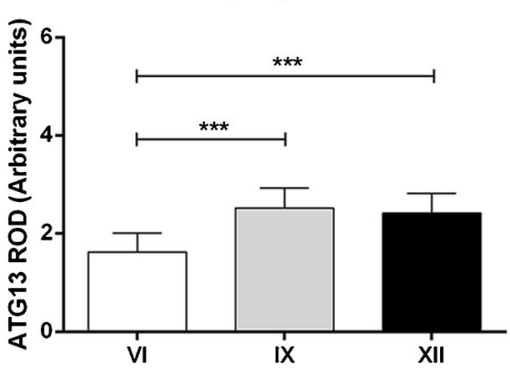

h

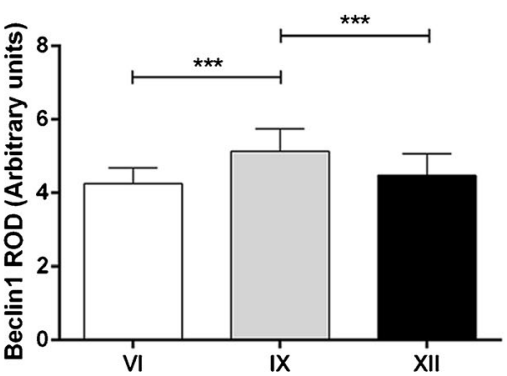

Sertoli cells
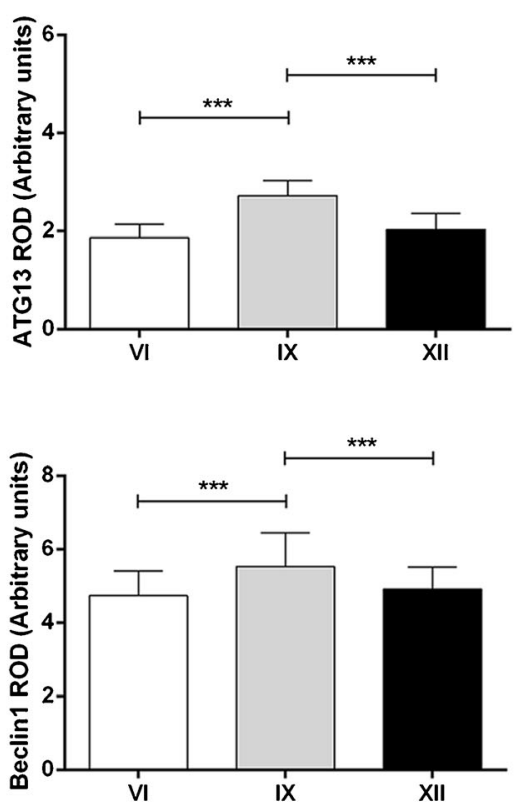

Germ cells
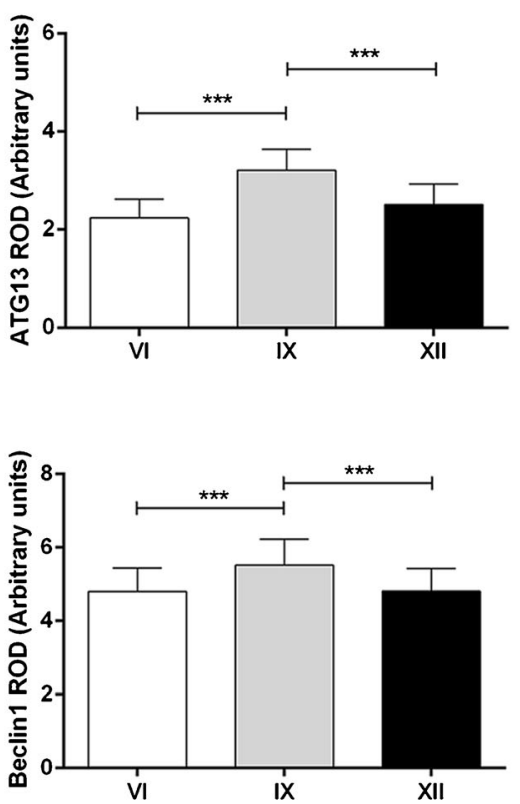

Fig. 4 Immunolocalization and intensity of immunohistochemical reaction for $\operatorname{Atg} 13(\mathbf{a}, \mathbf{b}, \mathbf{c}, \mathbf{g})$ and beclin1 $(\mathbf{d}, \mathbf{e}, \mathbf{f}, \mathbf{h})$ in the Leydig, Sertoli and germ cells of the European bison testis in June (VI), September (IX), and December (XII); negative controls are provided in

We showed a significant increase in the ULK1 kinase activity in the testis already at the nucleation stage, and this enzyme is a key regulator of the autophagy initiation (Wong et al. 2013). The activation of the ULK1 complex suggests an activation of phagophores formation, especially after the period of reproductive activity (Kim et al. 2011). At the phagophore forming stage, beclin1, Atg14 protein, and the PI3 kinase complex are also of crucial importance. The Atg14 protein is an essential factor affecting the autophagydependent phosphorylation of beclin1, but at the same time suppresses the PI3K phosphorylation by AMP-activated the right upper corners; magnification of the objective lens $(\mathbf{a}, \mathbf{b}, \mathbf{c}, \mathbf{d}, \mathbf{e}, \mathbf{f})$ $\times 10,\left(a^{\prime}, b^{\prime}, c^{\prime}, d^{\prime}, e^{\prime}, f^{\prime}\right) \times 20,\left(a^{\prime \prime}, b^{\prime \prime}, c^{\prime \prime}, d^{\prime \prime}, e^{\prime \prime}, f^{\prime \prime}\right) \times 40$. Bars indicate mean $\pm \mathrm{SD}, n=6, * * * p<0.001, * * p<0.01, * p<0.05$; no indication-no statistical significance

protein kinase (AMPK) (Fogel et al. 2013). It was shown that overexpression of Atg14 enhances autophagic activity in mammals (Xiong et al. 2012). In this study, we confirmed the upregulated expression of Atg14 both in September and December, and this may imply that this factor directly promotes autophagy in these months. The detailed analysis revealed a significant increase in the Atg14 localization in testicular germ and Sertoli cells. Atg14 is probably involved in the process of spermatogenesis inhibition, and it also may affect the interaction of these cells, and changes in their functions. The beclin 1 protein expression in the testis was the 

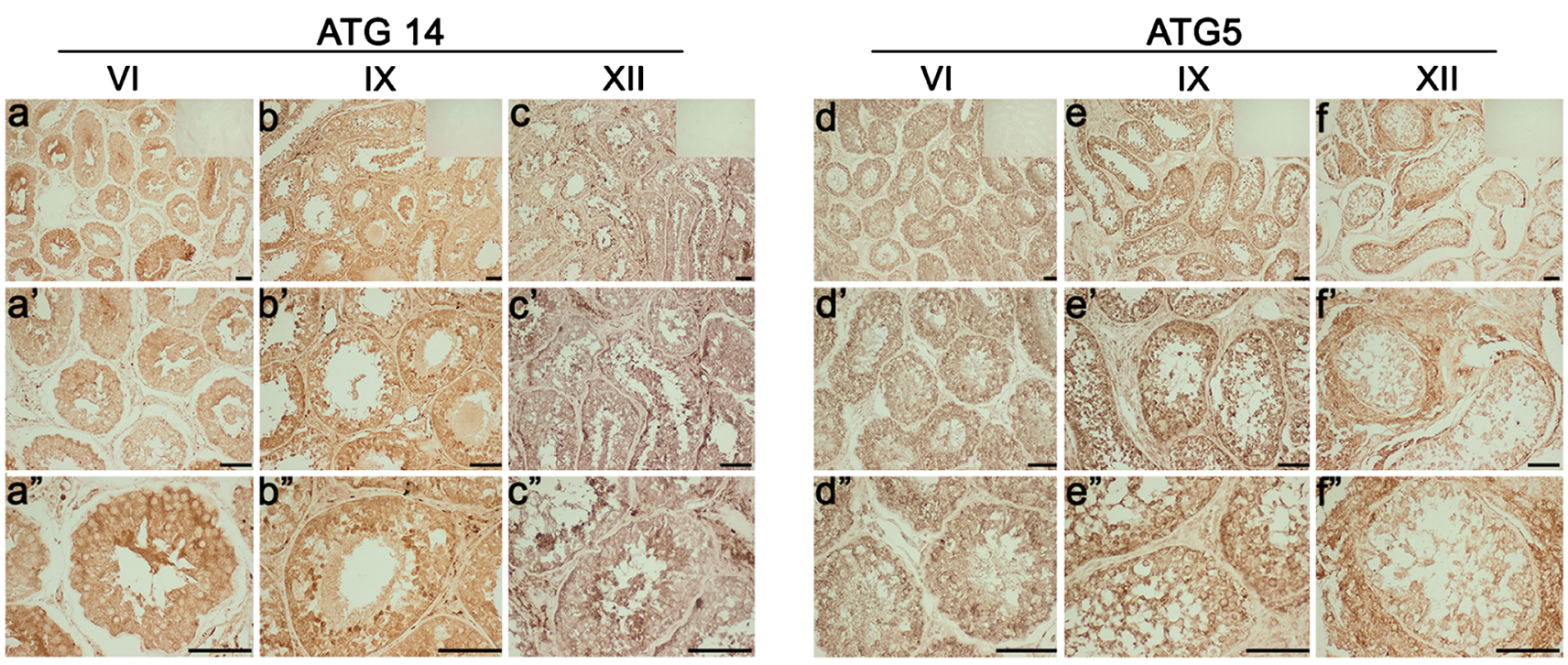

9

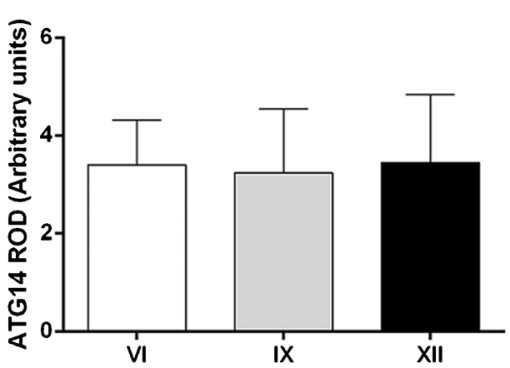

h

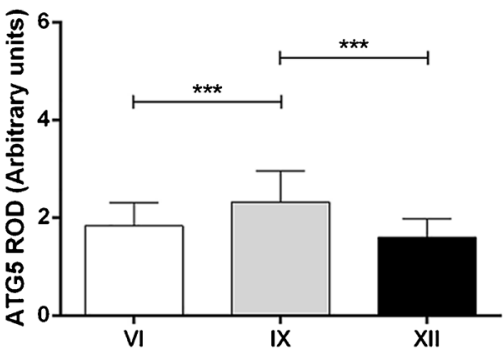

Fig. 5 Immunolocalization and intensity of immunohistochemical reaction for $\operatorname{Atg} 14(\mathbf{a}, \mathbf{b}, \mathbf{c}, \mathbf{g})$ and $\operatorname{Atg} 5(\mathbf{d}, \mathbf{e}, \mathbf{f}, \mathbf{h})$ in the Leydig, Sertoli, and germ cells of the European bison testis in June (VI), September (IX), and December (XII); negative controls are provided in

highest in December. It can be assumed that this protein is of the greatest importance for formation of a preautophagosomal structure in the period after the most intense reproductive activity, i.e., in December. On the other hand, the study of Liu et al. (2016) showed that autophagy plays a positive role in maintaining and survival of the reproductive cells (Liu et al. 2016). This may explain the noticeably raised beclin1 levels in Leydig, Sertoli, and germ cells in September. Furthermore, the activation of Atg12-Atg5-Atg16L complex enables the fusion between phagophores and autophagosomes. This complex is released from the
Germ cells
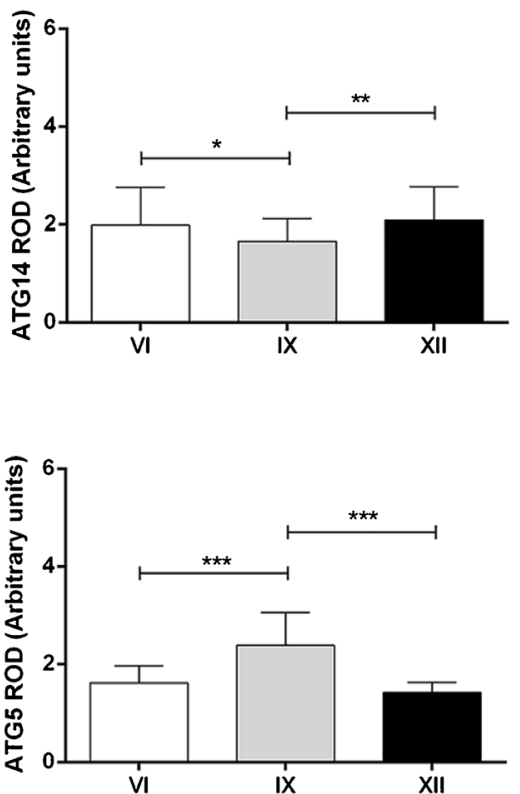

the right upper corners; magnification of the objective lens $(\mathbf{a}, \mathbf{b}, \mathbf{c}, \mathbf{d}, \mathbf{e}, \mathbf{f})$ $\times 10,\left(a^{\prime}, b^{\prime}, c^{\prime}, d^{\prime}, e^{\prime}, f^{\prime}\right) \times 20,\left(a^{\prime \prime}, b^{\prime \prime}, c^{\prime \prime}, d^{\prime \prime}, e^{\prime \prime}, f^{\prime \prime}\right) \times 40$. Bars indicate mean $\pm \mathrm{SD}, n=6, * * * p<0.001, * * p<0.01$, * $p<0.05$; no indication-no statistical significance

membrane just before or after its completion, so it is a good marker for the membrane isolation (Rubinsztein et al. 2012). Both in the testis and the epididymis, the highest level of the Atg16L expression was again observed in December. The activation of the above mentioned complex acts then as a LC3 (microtubule-associated protein 1 light chain 3), and its conversion from LC3 I to LC3 II is an excellent marker of autophagy (He and Klionsky 2009; Marino et al. 2014). In the European bison testis and epididymis, we found the upregulated expression of LC3 protein in December. A higher level of the LC3 expression was also observed in the testis and the 
epididymis in September; however, that difference was less pronounced. In studies in Lagostomus maximus, a seasonally breeding animal, reported by Gonzalez et al. (2018), the autophagy activation similarly varies in a season-dependent manner. During the testis regression, mRNA and protein expression for LC3 and beclin1 decreases, while in the period of the testis enlargement and return to the reproductive activity, the mRNA and protein expression of beclin 1 and LC3 increases (Gonzalez et al. 2018). Thus, our results, showing the high LC3 protein level in the testis in September, confirmed the discussed involvement of autophagy in maintaining homeostasis during the period of intense reproductive activity. Moreover, in the research of Gonzalez et al. (2018), a meaningful impact of the nutritional stress on the expression of autophagy-related genes was observed (Gonzalez et al. 2018). On a basis of involvement of two autophagic regulators, beclin1 and LC3, in germ, Leydig and Sertoli cells, it was suggested that autophagy could be the alternative mechanism of cell death. It can therefore be assumed that this process enables elimination of damaged germ cells or the cytoplasmic surplus of spermatids during spermatogenesis (Gonzalez et al. 2018; Zhang et al. 2012). Maintaining cellular homeostasis also means maintaining an appropriate level of energy through the degradation of components, depending on the actual demand (Kim and Lee 2014). The study of Pang et al. (2018) on prepubertal sheep test is showed that energy restriction resulted in the activation of autophagy through an increase in beclin1 and LC3 synthesis (Pang et al. 2018). It was also found that with reduced availability of energy, the mRNA and protein expression for BAX/beclin2 increased (Pang et al. 2018). These results can be compared with ours, where the spermatogenesis process in December is inhibited and energy is limited due to silencing of the reproductive activity. We confirmed that in the European bison, the beclin2 activation in December leads to activation of beclin1. It is highly likely that autophagy prepares cells for a change in their function, to save energy during the "reproductive silence." It must also be remembered that ambient temperatures during the breeding season are higher. Heat stress induces protein misfolding, denaturation, and aggregation in intracellular organelles (Lee et al. 2014), and by initiating autophagy those denatured proteins may regenerate some small-molecule substances (Son et al. 2011). Then autophagolysosomes are formed (Mizushima 2005). Autophagy may promote cell renewal, metabolism, and restoration of homeostasis in response to this type of cellular stress (Dokladny et al. 2015). In immature boar Sertoli cells, heat stress induced autophagy in a timedependent manner, where the highest expression of LC3 was noted after $24 \mathrm{~h}$ (Bao et al. 2017). On a basis of the results obtained in this study, we assume that heat stress can have some impact on the regulation of the seasonal activity of the European bison testes and the induction of autophagy in September.
Some of the factors that participate in the autophagy pathway are essential not only in autophagy, but they are very important for normal development of organs or tissues. In studies carried out in mice, it was demonstrated that Atg13 absence was manifested as growth retardation and myocardial growth defects in developing embryos (Kaizuka and Mizushima 2016). In the European bison testis, upregulated expression of Atg13 in September can contribute to the normal development of reproductive cells, for which the demand is the highest during this period. Intense localization of Atg13 in testicular Leydig, Sertoli, and germ cells seems to confirm its high involvement in spermatogenesis. Likewise, mTOR (mammalian target of rapamycin) is an environmental sensor that can reverse autophagy (Tan and Miyamoto 2016), but high levels of mTOR protein expression in September may suggest that a large amount of this protein is necessary for reproductive cells proliferation during the period of intense reproductive activity. It is known that mTOR kinase, assisted by amino acids and growth factors, affects the regulation of cell growth, transcription, translation, mRNA and ribosome formation, and proliferation (Huang and Fingar 2014; Mok et al. 2013). It was previously demonstrated in mice that mTOR is needed to differentiate spermatogonia (Busada et al. 2015a; Busada et al. 2015b). Also, the study by Sahin et al. (2018) suggested a role of the mTOR pathway in meiotic progress of male germ cells (Sahin et al. 2018), and it was shown earlier that changes in the autophagy activity can affect steroid secretion by Leydig cells (Lin and Baehrecke 2015; Yang et al. 2017; Yi and Tang 1995). On the basis of our results, we can suggest that high expression of Atg5 in the testis in September may be associated with spermatogenesis. Moreover, in the study on Sertoli cell-specific knockout of Atg5, subfertility due to the disorganized somniferous tubules and spermatozoa with malformed heads was observed. The obtained results revealed the role of autophagy in Sertoligerm cell communication by a proper formation of cytoskeleton and maintaining of the cytoplasmic cytoskeleton (Liu et al. 2016). In our study, the increased presence of Atg5 in Leydig and germ cells of the testis may confirm a high demand for this factor during intense spermatogenesis in September. In addition, in September, when intense cell proliferation occurs in the testes during spermatogenesis, the level of Nup62 protein expression in the epididymis was upregulated. This protein is an important regulator of the course of autophagy, because it determines the aggregation of proteins formed during the autophagy process and autophagosomes formation (Strambio-De-Castillia et al. 2010).

Concluding, the obtained results confirm that the autophagy process is a consequence of the European bison's seasonal reproduction, and therefore, can contribute to finding the cause of male infertility and an effective method for its prevention. However, it should be noted that the interpretation of the obtained results is highly hypothetical, because this report 
does not contain any evidence for the existence of the proposed mechanisms. The demonstrated changes in mRNA expression and protein synthesis of the autophagy signal pathway in testis and epididymis, however, seem to be important information confirming the involvement of this process in the proper course of the European bison reproductive function. They set a certain direction, which may be burdened with an error resulting from unforeseen changes in the course of biochemical and biological reactions

Author's contribution ATL: performed experiments, carried out data interpretation, wrote the paper, conceived and designed the experiments; JM: critically discussed the data, performed experiments; PS: critically discussed the data, prepared figures; MK: contributed materials, carried out data interpretation.

Funding The research was financed by the National Science Centre grant no. DEC-2017/01/X/NZ4/00331.

\section{Compliance with ethical standards}

Conflict of interest The authors declare that they have no conflicts of interest.

Ethical approval This article does not contain any studies with human participants or animals performed by any of the authors.

Open Access This article is distributed under the terms of the Creative Commons Attribution 4.0 International License (http:// creativecommons.org/licenses/by/4.0/), which permits unrestricted use, distribution, and reproduction in any medium, provided you give appropriate credit to the original author(s) and the source, provide a link to the Creative Commons license, and indicate if changes were made.

\section{References}

Aboelenain M, Kawahara M, Balboula AZ, Montasser Ael M, Zaabel SM, Okuda K, Takahashi M (2015) Status of autophagy, lysosome activity and apoptosis during corpus luteum regression in cattle. $\mathrm{J}$ Reprod Dev 61:229-236

Bao ZQ, Liao TT, Yang WR, Wang Y, Luo HY, Wang XZ (2017) Heat stress-induced autophagy promotes lactate secretion in cultured immature boar Sertoli cells by inhibiting apoptosis and driving SLC2A3, LDHA, and SLC16A1 expression. Theriogenology 87: 339-348

Bartsch G, Jennewein L, Harter PN, Antonietti P, Blaheta RA, Kvasnicka HM, Kogel D, Haferkamp A, Mittelbronn M, Mani J (2016) Autophagy-associated proteins BAG3 and p62 in testicular cancer. Oncol Rep 35:1629-1635

Busada JT, Chappell VA, Niedenberger BA, Kaye EP, Keiper BD, Hogarth CA, Geyer CB (2015a) Retinoic acid regulates Kit translation during spermatogonial differentiation in the mouse. Dev Biol 397:140-149

Busada JT, Niedenberger BA, Velte EK, Keiper BD, Geyer CB (2015b) Mammalian target of rapamycin complex 1 (mTORC1) Is required for mouse spermatogonial differentiation in vivo. Dev Biol 407:90 102

Dokladny K, Myers OB, Moseley PL (2015) Heat shock response and autophagy-cooperation and control. Autophagy 11:200-213
Eisenberg-Lerner A, Bialik S, Simon HU, Kimchi A (2009) Life and death partners: apoptosis, autophagy and the cross-talk between them. Cell Death Differ 16:966-975

Fogel AI, Dlouhy BJ, Wang C, Ryu SW, Neutzner A, Hasson SA, Sideris DP, Abeliovich H, Youle RJ (2013) Role of membrane association and Atg14-dependent phosphorylation in beclin-1-mediated autophagy. Mol Cell Biol 33:3675-3688

Gonzalez CR, Muscarsel Isla ML, Vitullo AD (2018) The balance between apoptosis and autophagy regulates testis regression and recrudescence in the seasonal-breeding South American plains vizcacha, Lagostomus maximus. PLoS One 13:e191126

He C, Klionsky DJ (2009) Regulation mechanisms and signaling pathways of autophagy. Annu Rev Genet 43:67-93

Huang K, Fingar DC (2014) Growing knowledge of the mTOR signaling network. Semin Cell Dev Biol 36:79-90

Huang C, Li X (2014) Maternal cypermethrin exposure during the perinatal period impairs testicular development in C57BL male offspring. PLoS One 9:e96781

Kaizuka T, Mizushima N (2016) Atg13 Is essential for autophagy and cardiac development in mice. Mol Cell Biol 36:585-595

Kim KH, Lee MS (2014) Autophagy as a crosstalk mediator of metabolic organs in regulation of energy metabolism. Rev Endocr Metab Disord 15:11-20

Kim GJ, Georg I, Scherthan H, Merkenschlager M, Guillou F, Scherer G, Barrionuevo F (2010) Dicer is required for Sertoli cell function and survival. Int J Dev Biol 54:867-875

Kim J, Kundu M, Viollet B, Guan KL (2011) AMPK and mTOR regulate autophagy through direct phosphorylation of Ulk1. Nat Cell Biol 13: 132-141

Kim YS, Lee HM, Kim JK, Yang CS, Kim TS, Jung M, Jin HS, Kim S, Jang J, Oh GT, Kim JM, Jo EK (2017) PPAR-alpha activation mediates innate host defense through induction of TFEB and lipid catabolism. J Immunol 198:3283-3295

Lee E, Koo Y, Ng A, Wei Y, Luby-Phelps K, Juraszek A, Xavier RJ, Cleaver O, Levine B, Amatruda JF (2014) Autophagy is essential for cardiac morphogenesis during vertebrate development. Autophagy 10:572-587

Levine B, Klionsky DJ (2004) Development by self-digestion: molecular mechanisms and biological functions of autophagy. Dev Cell 6:463477

Li WR, Chen L, Chang ZJ, Xin H, Liu T, Zhang YQ, Li GY, Zhou F, Gong YQ, Gao ZZ, Xin ZC (2011) Autophagic deficiency is related to steroidogenic decline in aged rat Leydig cells. Asian J Androl 13: 881-888

Lin L, Baehrecke EH (2015) Autophagy, cell death, and cancer. Mol Cell Oncol 2:e985913

Liu C, Wang H, Shang Y, Liu W, Song Z, Zhao H, Wang L, Jia P, Gao F, $\mathrm{Xu}$ Z, Yang L, Li W (2016) Autophagy is required for ectoplasmic specialization assembly in sertoli cells. Autophagy 12:814-832

Marcais A, Blevins R, Graumann J, Feytout A, Dharmalingam G, Carroll T, Amado IF, Bruno L, Lee K, Walzer T, Mann M, Freitas AA, Boothby M, Fisher AG, Merkenschlager M (2014) microRNAmediated regulation of mTOR complex components facilitates discrimination between activation and anergy in CD4 T cells. J Exp Med 211:2281-2295

Marino G, Niso-Santano M, Baehrecke EH, Kroemer G (2014) Self-consumption: the interplay of autophagy and apoptosis. Nat Rev Mol Cell Biol 15:81-94

McGuire NL, Kangas K, Bentley GE (2011) Effects of melatonin on peripheral reproductive function: regulation of testicular $\mathrm{GnIH}$ and testosterone. Endocrinology 152:3461-3470

Mizushima N (2005) The pleiotropic role of autophagy: from protein metabolism to bactericide. Cell Death Differ 12(Suppl 2):15351541

Mizushima N, Levine B (2010) Autophagy in mammalian development and differentiation. Nat Cell Biol 12:823-830 
Mok KW, Mruk DD, Cheng CY (2013) Regulation of blood-testis barrier (BTB) dynamics during spermatogenesis via the "Yin" and "Yang" effects of mammalian target of rapamycin complex 1 (mTORC1) and mTORC2. Int Rev Cell Mol Biol 301:291-358

Ouimet M, Koster S, Sakowski E, Ramkhelawon B, van Solingen C, Oldebeken S, Karunakaran D, Portal-Celhay C, Sheedy FJ, Ray TD, Cecchini K, Zamore PD, Rayner KJ, Marcel YL, Philips JA, Moore KJ (2016) Mycobacterium tuberculosis induces the miR-33 locus to reprogram autophagy and host lipid metabolism. Nat Immunol 17:677-686

Pang J, Li F, Feng X, Yang H, Han L, Fan Y, Nie H, Wang Z, Wang F, Zhang Y (2018) Influences of different dietary energy level on sheep testicular development associated with AMPK/ULK1/autophagy pathway. Theriogenology 108:362-370

Rubinsztein DC, Shpilka T, Elazar Z (2012) Mechanisms of autophagosome biogenesis. Curr Biol 22:R29-R34

Sahin P, Gungor-Ordueri NE, Celik-Ozenci C (2018) Inhibition of mTOR pathway decreases the expression of pre-meiotic and meiotic markers throughout postnatal development and in adult testes in mice. Andrologia 50

Schmidt JA, de Avila JM, McLean DJ (2007) Analysis of gene expression in bovine testis tissue prior to ectopic testis tissue xenografting and during the grafting period. Biol Reprod 76:1071-1080

Singh S, Canseco DC, Manda SM, Shelton JM, Chirumamilla RR, Goetsch SC, Ye Q, Gerard RD, Schneider JW, Richardson JA, Rothermel BA, Mammen PP (2014) Cytoglobin modulates myogenic progenitor cell viability and muscle regeneration. Proc Natl Acad Sci U S A 111:E129-E138

Son YO, Wang X, Hitron JA, Zhang Z, Cheng S, Budhraja A, Ding S, Lee JC, Shi X (2011) Cadmium induces autophagy through ROSdependent activation of the LKB1-AMPK signaling in skin epidermal cells. Toxicol Appl Pharmacol 255:287-296

Strambio-De-Castillia C, Niepel M, Rout MP (2010) The nuclear pore complex: bridging nuclear transport and gene regulation. Nat Rev Mol Cell Biol 11:490-501

Tabecka-Lonczynska A, Mytych J, Solek P, Kulpa M, Koziorowski M (2017) New insight on the role of melatonin receptors in reproductive processes of seasonal breeders on the example of mature male European bison (Bison bonasus, Linnaeus 1758). J Photochem Photobiol B 173:84-91

Tabecka-Lonczynska A, Mytych J, Solek P, Kulpa-Greszta M, Koziorowski M (2018a) Melatonin receptors subtypes (MT1 and MT2) in the uterus masculinus of mature male european bison. Biological and seasonal reproductive role. J Physiol Pharmacol 69: $67-73$
Tabecka-Lonczynska A, Mytych J, Solek P, Kulpa-Greszta M, SowaKucma M, Koziorowski M (2018b) Vascular endothelial growth factor (VEGF-A) and fibroblast growth factor (FGF-2) as potential regulators of seasonal reproductive processes in male European bison (Bison bonasus, Linnaeus 1758). Gen Comp Endocrinol 263: 72-79

Tan VP, Miyamoto S (2016) Nutrient-sensing mTORC1: Integration of metabolic and autophagic signals. J Mol Cell Cardiol 95:31-41

Thomas S, Thomas M, Wincker P, Babarit C, Xu P, Speer MC, Munnich A, Lyonnet S, Vekemans M, Etchevers HC (2008) Human neural crest cells display molecular and phenotypic hallmarks of stem cells. Hum Mol Genet 17:3411-3425

Wang H, Wan H, Li X, Liu W, Chen Q, Wang Y, Yang L, Tang H, Zhang X, Duan E, Zhao X, Gao F, Li W (2014) Atg7 is required for acrosome biogenesis during spermatogenesis in mice. Cell Res 24:852869

Wen X, Klionsky DJ (2016) An overview of macroautophagy in yeast. J Mol Biol 428:1681-1699

Wong PM, Puente C, Ganley IG, Jiang X (2013) The ULK1 complex: sensing nutrient signals for autophagy activation. Autophagy 9:124 137

Xiong X, Tao R, DePinho RA, Dong XC (2012) The autophagy-related gene 14 (Atg14) is regulated by forkhead box $\mathrm{O}$ transcription factors and circadian rhythms and plays a critical role in hepatic autophagy and lipid metabolism. J Biol Chem 287:39107-39114

Yang Z, Klionsky DJ (2010) Mammalian autophagy: core molecular machinery and signaling regulation. Curr Opin Cell Biol 22:124 131

Yang W, Li L, Huang X, Kan G, Lin L, Cheng J, Xu C, Sun W, Cong W, Zhao S, Cui S (2017) Levels of Leydig cell autophagy regulate the fertility of male naked mole-rats. Oncotarget 8:98677-98690

Yi J, Tang XM (1995) Functional implication of autophagy in steroidsecreting cells of the rat. Anat Rec 242:137-146

Zhang M, Jiang M, Bi Y, Zhu H, Zhou Z, Sha J (2012) Autophagy and apoptosis act as partners to induce germ cell death after heat stress in mice. PLoS One 7:e41412

Zielniok K, Sobolewska A, Gajewska M (2017) Mechanisms of autophagy induction by sex steroids in bovine mammary epithelial cells. J Mol Endocrinol 59:29-48

Zirkin BR, Papadopoulos V (2018) Leydig cells: formation, function, and regulation. Biol Reprod 99:101-111

Publisher's note Springer Nature remains neutral with regard to jurisdictional claims in published maps and institutional affiliations. 